\title{
Kearifan lokal sebagai modal sosial dalam integrasi antara etnik Bali dan etnik Bugis di desa Petang, Badung, Bali
}

\author{
Nyoman Suryawan \\ IKIP Saraswati, Tabanan, Bali \\ Email : suryawannyoman@rocketmail.com
}

\begin{abstract}
Abstrak
Desa Petang yang secara administratif berada dalam wilayah Kabupaten Badung menyimpan keunikan sendiri. Di dalam masyarakatnya yang sebagian besar beragama Hindu, ternyata dijumpai adanya warga Bugis yang beragama Islam yang hidup rukun dan damai hingga sekarang. Begitu kuatnya hubungan persaudaraan yang dibangun antaretnik tersebut menyebabkan mereka lebih akrab menyebutnya dengan istilah menyama braya. Penulisan artikel ini bertujuan selain untuk mengetahui tentang keberadaan etnik Bugis di Angantiga, juga memahami bentuk-bentuk kearifan lokal yang dapat mengintegrasikan antara etnik Bugis dan etnik Bali di daerah tersebut. Analisis data dalam penelitian ini dilakukan melalui pendekatan diskriptif kualitatif. Sedangkan teknik pengumpulan data mencakup, observasi partisipatif, wawancara mendalam, dan dokumentasi. Hasil penelitian menunjukkan bahwa eratnya hubungan persaudaraan antara etnik Bali dan etnik Bugis di Angantiga tidak dapat dilepaskan dari faktor historis terkait dengan peran Puri Carangsari yang memberikan tempat bagi warga Bugis di daerah tersebut. Selain itu, faktor pengintegrasi lainya adalah adanya perkawinan antarwarga, adopsi budaya, serta kearifan lokal baik yang terkait dengan nilai ataupun jaringan sosial yang diimplementasikan sebagai landasan atau pedoman dalam berinteraksi antara satu dengan lainnya.
\end{abstract}

Kata kunci: kearifan lokal, modal sosial, integrasi, etnik

\begin{abstract}
Petang village that is administratively located in Badung regency keep its own uniqueness. In their communities who are largely Hindu, was found the Bugis Muslim citizens who live in harmony and peace up to now. So powerful
\end{abstract}


built brotherly relations between the different ethnic cause them more familiar with the term behave Braya call. Writing this article aims in addition to knowing about the existence of ethnic Bugis in Angantiga, also understand the forms of local wisdom that can integrate between ethnic Bugis and ethnic Balinese. Data were collected through participant observation, in-depth interviews, and documentation. They were analysed by descriptive qualitative approach. The results showed that the close brotherhood relations between ethnic Balinese and ethnic Bugis in Angantiga cannot be separated from the historical factors related to the royal role (Puri) Carangsari that provides a place for residents in the area Bugis. In addition, integrating other factor is the marriage between citizens, cultural adoption, as well as good local knowledge associated with the value or social network that is implemented as a foundation or guidelines in their interaction with one another.

Keywords: local knowledge, social capital, integration, ethnic

\section{Pendahuluan}

N $\begin{aligned} & \text { egara Indonesia dengan ribuan pulau yang terbentang dari } \\ & \text { Sabang hingga Merauke dihuni oleh beragam suku dengan }\end{aligned}$ segala adat dan budayanya. Selain itu negara ini juga dihuni oleh agama-agama besar yang dianut oleh rakyat Indonesia hingga kini. Secara resmi terdapat 6 agama yang tumbuh dan menjadi pedoman untuk menjalankan hidup bagi Bangsa Indonesia, yaitu Hindu, Budha, Islam, Kristen Katolik, Kristen Protestan, dan Khonghucu.

Secara etnis di Indonesia terdapat sekitar 3000 suku bangsa yang masing-masing memiliki identitas kebudayaan tersendiri (Liliweri, 2005:6). Setiap etnik atau suku bangsa tersebut pada umumnya akan memiliki territorial dengan bahasa dan budaya sendiri yang berbeda dengan yang dimiliki oleh etnik yang lain. Keberagaman etnik dengan variasi budaya yang dimiliki Negara Indonesia tersebut, di satu sisi jika dikelola dengan baik akan menjadi aset bangsa yang tak ternilai harganya dikaitkan dengan promosi pariwisata untuk lebih dikenal oleh dunia. Akan tetapi, di lain pihak apabila kemajemukan tersebut tidak dapat dikelola dengan baik justru akan rentan menimbulkan terjadinya konflik SARA yang dapat menghancurkan bangsa ini. 
Sehubungan dengan itu multikulturalisme sebagai sebuah paham pengahargaan terhadap perbedaan terkait dengan keberagaman perlu diketengahkan. Hal tersebut sesuai dengan yang terkandung dalam pengertian multikulturalisme sebagai upaya jujur untuk menata masyarakat yang plural atau majemuk menjadi masyarakat yang multikulturalistik yang harmonis dan dinamis melalui penghargaan terhadap kebebasan dan kesetaraan manusia (Molan, 2015:33).

Dalam konsep tersebut multikulturalisme muncul sebagai upaya untuk membangun masyarakat yang memiliki aneka ragam budaya agar bisa hidup bersama setara tanpa pembedaan etnis, ras ataupun agama yang berbeda antara satu dengan lainnya. Kebebasan dan kesetaraan adalah prinsip etis yang harus terus dibangun dalam masyarakat yang multikulturalistik sebagaimana diatur dalam perundang-undangan yang berlaku.

Bali sebagai bagian dari wilayah Indonesia yang terkenal akan destinasi pariwisatanya, juga memiliki keragaman etnik maupun agama yang dianut oleh warganya. Secara historis daerah ini pertama kali dihuni oleh etnik Bali yang beragama Hindu, kemudian seiring dengan perkembangan zaman, jumlah etnik yang mendiami pulau ini semakin bertambah, baik yang disebabkan karena faktor migrasi maupun yang didorong oleh motivasi lain seperti politik maupun ekonomi.

Terkait dengan keberagaman budaya, Desa Petang yang berlokasi di wilayah Badung utara terdapat fenomena yang unik. Di tengah warga Bali yang beragama Hindu dan bernaung dalam wadah desa adat terdapat kampung Bugis beragama Islam yang hingga kini hidup berdampingan secara damai. Praktik multikulturalisme benar-benar dapat dijalankan secara baik di antara dua etnik tanpa saling merendahkan satu dengan yang lain. Kearifan lokal yang dimiliki telah menjadi modal sosial yang mampu berfungsi sebagai perekat integrasi di antara kedua etnik yang berbeda. Bertolak dari kondisi tersebut yang perlu digali adalah bagaimana keberadaan kantong Bugis di Desa Petang, Badung dan apa sajakah yang menjadi pendorong sehingga terjadinya integrasi antara etnik Bugis dan Bali di daerah tersebut?

Penelitian ini menggunakan analisis kualitatif untuk menghasilkan data yang bersifat diskriptif dari objek yang diteliti. Lokasi penelitian dilakukan di Desa Petang, Badung utara dengan 
pertimbangan bahwa di daerah tersebut terdapat fakta toleransi antaretnik yang amat kental antara etnik minoritas Bugis yang beragama Islam dengan etnik mayoritas Bali yang beragama Hindu. Hubungan tersebut masih tetap terbina sejak zaman kerajaan hingga sekarang.

Informan dalam penelitian ini adalah masyarakat yang ada di Desa Petang baik yang beragama Islam maupun Hindu. Penentuan informan dilakukan melalui cara snowball yang diawali dengan penunjukan informan kunci sebagai informan utama. Selanjutnya informan ini akan memberikan informasi terhadap informan berikutnya. Oleh sebab itu, dalam penelitian ini besarnya informan tidak dibatasi.

Teknik pengumpulan data yang digunakan mencakup, observasi partisipatif, wawancara mendalam, dan dokumentasi. Analisis data dilakukan secara kualitatif melalui beberapa langkah tertentu yaitu, penggalian data, katagorisasi data, penyusunan data dan dialanjutkan dengan interpretasi data melalui pendekatan diskriptif kualitatif (Bogdan dan Taylor 1975). Melalui cara tersebut akan diperoleh gambaran riil tentang praktik multikulturalisme yang dijalani masyarakat di Desa Petang, Badung.

\section{Kampung Bugis dan keberadaannya di desa Petang}

Kampung Angantiga adalah salah satu banjar (dusun) yang secara administratif termasuk dalam wilayah Desa Petang, Badung. Kampung ini dahulu lebih dikenal dengan sebutan Kampung Bugis Angantiga karena penduduknya adalah etnik Bugis. Akan tetapi, belakangan kampung ini lebih populer dengan sebutan kampung Islam karena penghuninya bukan saja dari etnik Bugis, tetapi juga dari etnik lain yang beragama Islam.

Kampung Islam Angantiga tergabung dalam wilayah Banjar Dinas Angantiga bersama dengan banjar adat Angantiga. Dengan demikian, di wilayah Banjar Dinas Angantiga akan membawahi dua komunitas, yakni komunitas Hindu yang tergabung dalam banjar adat dan komunitas muslim yang tergabung dalam Kampung Islam Angantiga.

Keberadaan kedua komunitas tersebut, meskipun berbeda dalam agama dan keyakinan, tetapi mereka tetap menjalin hubungan yang harmonis di antara keduanya semenjak ratusan tahun yang lalu hingga sekarang. Etnik Bugis tersebut diperkirakan 
telah ada semenjak tahun 1442, semenjak dibuka oleh tiga tokoh Bugis (Haryanto, 2010).

Berdasarkan data yang diperoleh dari beberapa sumber, keberadaan kampung Bugis Angantiga menurut Muchlis Cahyadi, Kepala Kampung Islam Angantiga di antaranya bersumber dari Purana Carang Sari (Wawancara, 15 Mei 2016).

Dalam lontar purana tersebut dikemukakan bahwa pada masa Kerajaan Carangsari dengan rajanya yang memerintah ketika itu yaitu Ida Gusti Ngemengkurat Kacung Gede, memiliki masalah dengan wilayahnya yang bernama Bangkiang Jaran. Daerah ini konon kondisinya sangat rawan karena merupakan jalan setapak yang pada bagian kiri dan kanannya adalah berupa jurang. Kondisi daerah tersebut dianggap sangat rawan, karena setiap warga yang akan bepergian ke Puri Carangsari sering menerima gangguan dan bahkan banyak yang hilang. Pihak puri kemudian meminta bantuan pada tiga orang Bugis yang saat itu ditemukan di Perairan Angantelu, Karangasem.

Ketiga orang Bugis yang belakangan dikenal sebagai bangsawan tersebut diminta untuk mengamankan daerah Bangkiang Jaran yang dianggap rawan. Keberhasilan dari orang Bugis tersebut untuk menjalankan tugasnya menyebabkan daerah yang sebelummya dianggap rawan tersebut kemudian berubah menjadi aman. Sebagai penghormatan dan rasa terima kasih terhadap usahanya tersebut, raja kemudian menghadiahkan ketiga warga Bugis yang dipimpin oleh Daeng Mapilih untuk menempati daerah itu dan berkembang hingga sekarang.

Selanjutnya, nama daerah tersebut kemudian dikenal dengan Angantiga yang menurut istilah setempat memberikan makna yang beragam. Seperti angantiga berasal dari kata "aman tiga" yaitu mengacu pada daerah yang menjadi aman karena jasa dari ketiga orang Bugis tersebut. Atau ada yang mengatakan Angantiga terkait dengan tiga Bugis yang ditemukan di perairan Angantelu Karangasem.

Dalam purana yang disebutkan oleh tokoh Puri Carangsari, dikemukakan bahwa Bugis di daerahnya sudah ada pada tahun 1542 dan diyakini bahwa ketiga bangsawan Bugis dimaksud adalah Daeng Mapilih, Daeng Sarekah, dan Daeng Syafi'ie (Suwita, 2014). Suwita dalam pandangannya juga mengatakan bahwa secara historis usia Kampung Bugis yang sekarang bernama Kampung 
Islam Angantiga tersebut termasuk katagori paling tua bersama dengan Kampung Bugis lainnya yang ada di Bali selatan.

Sebagai penguat adanya sejarah yang menyatakan bahwa orang Bugis pertama kali menempati daerah Angantiga, di kuburan setempat ditemukan adanya peninggalan berupa tiga buah makam kuno. Makam pertama dengan tulisan Daeng Mapilih wafat 16 Ramadhan 1328 H/1908 M. Tulisan tersebut mengacu pada waktu ditemukannya makam tersebut. Saat ini makam dimaksud sudah dipugar dan diberi cangkup, sedangkan dua makam lainnya batu nisannya masih asli berbentuk batan, satu polos dan lainnya diujungnya bercorak segi delapan dengan sinarnya (Ismail, 2010). Walaupun demikian menurutnya, hingga sekarang masih belum dipastikan siapa pemilik dari dua makam tersebut.

Selain versi purana Carangsari yang disebutkan, di masyarakat juga berkembang versi yang lain. Kepala Kampung Islam Muchlis Cahyadi pernah mendengar adanya cerita dari para tetua setempat yang mengatakan bahwa sebelumnya ada serombongan perahu Bugis yang mendarat di Tuban. Sang pemimpin kemudian menyuruh 3 anak buahnya untuk mencari air. Di tengah jalan mereka bertemu dengan orang-orang yang sedang sabung ayam (tajen). Saat melihat darah terluka dari ayam yang diadu tersebut, mereka kemudian mengatakan cela yang dalam bahasa Bugis berarti darah. Akan tetapi, dalam Bahasa Bali berarti kemaluan laki-laki. Oleh sebab itu, orang-orang Bali tersebut kemudian marah dan menghajar mereka, tetapi orang tersebut ternyata sangat tangguh dan yang mengeroyok justru bisa dikalahkan. Atas kejadian itu raja akhirnya memanggil mereka untuk menghadap dan disuruh mengabdi untuk memerangi musuh-musuhnya.

Dari beberapa versi yang mengungkapkan tentang keberadaan Angantiga tersebut, masyarakat setempat lebih cendrung untuk menerima pandangan pertama bersumber dari Purana Carangsari yang menyebutkan bahwa wilayah Angantiga dahulunya adalah daerah alas Bangkiang Jaran yang pertama kali dibuka dan dihuni oleh pendatang dari Bugis dibawah pimpinan Daeng Mapilih.

\section{Kearifan lokal sebagai modal sosial integrasi antaretnik}

Setiap masyarakat dalam kehidupannya niscaya akan memiliki kearifan sendiri yang dipergunakan sebagai pedoman untuk berinteraksi antara satu dengan yang lain ataupun dalam merespons 


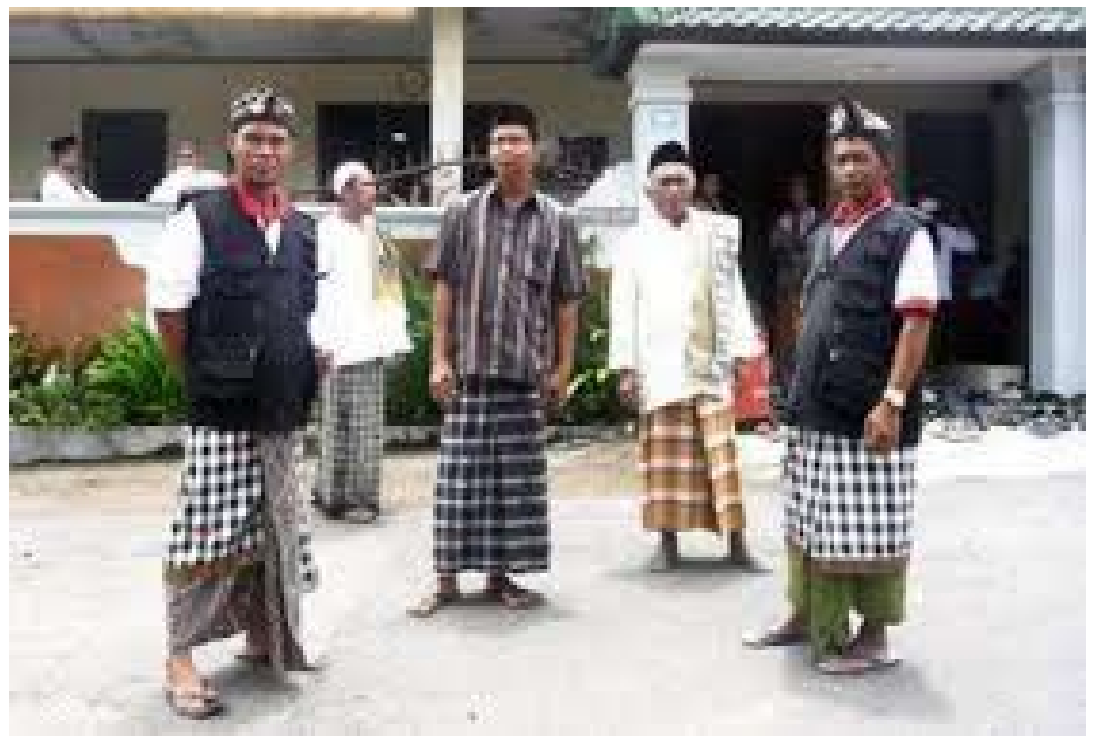

Foto 1. Indahnya Kebersamaan (Doc. Penulis)

lingkungannya. Kearifan sosial tersebut selanjutnya akan berperan sebagai modal sosial bagi masyarakat untuk menumbuhkan saling percaya di antara mereka.

Fukuyama dalam Duija (2005:210) mengartikan modal sosial sebagai sebuah konsepsi nilai dimana orang memiliki hubungan sosial dengan saling mengharapkan yang dilandasi oleh nilai kejujuran kesopanan, kesetiaan dan sebagainya. Secara sederhana modal sosial dapat diartikan sebagai seperangkat nilai atau norma informal yang dimiliki bersama oleh anggota suatu kelompok yang memungkinkan mereka dapat bekerja sama satu dengan yang lainnya. Sehubungan dengan itu, dalam modal sosial terkandung nilai kejujuran yang hakiki untuk akhirnya dapat saling percaya dalam praktik berkehidupan.

Kearifan lokal sebagai modal sosial dapat dilihat dari dimensi pranata atau nilai dan dimensi jaringan sosial. Kearifan sosial dalam tatanan pranata umumnya dinyatakan dalam hubungan relasi yang terjadi antarmasyarakat tanpa memandang agama maupun etnis seperti yang tercermin dalam pandangan tat twam asi. Demikian juga terkait dengan konsep nilai yang mengatur hubungan harmonis antara manusia dengan Tuhan, manusia dengan manusia maupun manusia dengan alam sebagaimana terkandung dalam filsafat tri hita karana. 
Dalam dimensi jaringan sosial dinyatakan kearifan lokal dinyatakan dalam bentuk hubungan-hubungan sosial yang terjadi di masyarakat yang diwujudkan melalui tindakan tolong menolong antarsesama sehingga akan terbentuk kebersamaan untuk merasa senasib sepenanggungan. Sifat saling percaya yang dibalut dengan rasa kebersamaan akan menjadi modal sosial yang kuat untuk terciptanya kerukunan dan kedamaian di antara masyarakat.

Masyarakat Angantiga yang terletak di Desa Petang, Badung memiliki kearifan lokal yang hingga sekarang masih terpelihara dengan baik dalam bentuk nilai-nilai sosial yang dipraktikkan sebagai pedoman dalam kehidupan sehari-hari antara etnik Bugis dan etnik Bali. Kearifan tersebut selanjutnya telah mendorong teruwudnya integrasi sosial di antara mereka

Adapun faktor pendorong integrasi sosial antaretnik Bugis dan Bali sebagaimana dimaksud adalah.

\section{Keterikatan historis}

Sebagaimana dikemukakan sebelumnya bahwa keberadaan etnik Bugis yang beragama Islam di Desa Petang (Badung) tidak dapat dilepaskan dari Kerajaan Carangsari ketika itu. Hubungan tersebut hingga kini masih berlanjut, artinya kalau pihak Puri memiliki hajatan dalam upacara yadnya misalnya, warga Bugis dengan senang hati akan ikut ngayah atau menyumbangkan tenaganya secara sukarela untuk membantu dalam mensukseskan acara tersebut. Sebaliknya ketika warga Bugis memperingati acara penting seperti Idul Fitri, pihak Puri turut pula diundang sebagai bentuk silaturahmi yang bermakna ada persatuan di antara mereka yang tidak pernah terlupakan. Hubungan kaula - gusti (Patron -Client) yang diperankan antara Raja dan warga Bugis begitu sangat ketalnya sehingga mereka seperti bersaudara sedarah (Pageh, 2013). Kondisi tersebut dibuktikan oleh warga Angantiga meskipun hidup berdampingan, kedua etnik berbeda agama tersebut tidak pernah terjadi gesekan yang berarti di antara keduanya.

Begitu kuatnya hubungan antara Bugis (muslim) Angantiga dengan Puri Carangsari, untuk mengajegkannya, maka pihak puri senantiasa mewariskan tradisi yang dilakoni pendahulunya. Hingga kini, pihak Puri Carangsari selalu menyambut undangan yang disampaikan oleh warga muslim untuk hadir seperti dalam acara Idul Fitri maupu Idul Adha. Demikian pula sebaliknnya 
Warga Muslim akan senang hati ikut membantu (ngayah) pada saat di Puri memiliki hajatan tertentu seperti piodalan atapun kegiatan lainnya.

\section{Perkawinan campur}

Adanya perkawinan antarwarga Bugis dengan warga Bali (Hindu) telah terjadi semenjak lama dan melahirkan generasi yang hidup secara damai hingga kini. Masyarakat di Angantiga sebenarnya masih saling terkait hubungan saudara antara satu dengan lainnya. Banyak pemuda muslim yang menikahi perempuan Bali, demikian sebaliknya banyak pula pemuda Bali yang menikahi perempuan Bugis. Sebagai akibatnya keluarga-keluarga tersebut telah berkembnag hingga saat ini dan terjalin hubungan kekerabatan yang sangat erat. Begitu eratnya hubungan di antara keduanya sehingga dikenal adanya sebutan nyama (saudara) selam yang diberikan sebagai sebutan oleh umat Bali pada warga Bugis. Sebaliknya warga Bugis menganggap warga Bali dengan sebutan nyama (saudara) Bali.

Keakraban yang dibangun melalui persaudaraan antara etnik Bugis dengan etnik Bali dan tumbuh dari kesatuan individuindividu yang saling berhubungan dan saling membutuhkan antara satu dengan yang lainnya akan menciptakan adanya persatuan di antara mereka. Dalam konteks tersebut, setiap warga akan menganggap warga yang lain sebagai nyama (saudara) akan memunculkan ikatan sosial yang kuat sehingga tercipta kerukunan bersama yang akhirnya mendukung ketentraman di masyarakat. Keterlibatan masyarakat secara bersama, selain merupakan tuntutan sosial juga sekaligus menunjukkan adanya pengakuan terhadap keberadaan dari individu lainnya sebagaimana tercermin dalam konsep multikulturalisme.

\section{Keterlibatan dalam organisasi sosial}

Warga Bugis di Angantiga telah lama dilibatkan dalam organisasi sosial seperti seka teruna-teruni sebagai wadah generasi muda dalam melaksanakan kegiatan, organisasi pertanian seperti subak abian yang menghimpun mayarakat petani yang memiliki lahan kering yang sudah ditanami dengan tanaman kopi ataupun cengkeh. Kedua organisasi tersebut dalam praktiknya tidak diskriminatif, tetapi telah melibatkan kedua etnik sebagai upaya bersama 
dalam membangun desa. Selain itu penunjukan personal yang menduduki posisi secara formal di banjar dinas sering dilakukan secara bergantian antara etnik Bugis dan Bali.

Selain itu keterlibatan antarkedua etnik, baik Bali maupun Bugis juga tampak dalam keanggotaan posyandu dan juga dalam keanggotaan PKK setempat yang masih bertahan hingga sekarang. Keterlibatan anggota masyarakat tanpa memandang agama maupun etnik dalam organisisi sosial apapun bentuknya akan mendukung terjadinya integrasi atau pembauran di antara warga masyarakat.

\section{Nilai dan norma sosial}

Bali sebagai pulau kecil namun eksotik menyimpan keragaman budaya yang tak terhingga yang berfungsi sebagai magnet yang dapat menarik wisatawan untuk datang menikmatinya. Daya tarik dimaksud melekat pada masyarakat dalam bentuk berbagai kearifan lokal yang dimilikinya. Dalam pandangan Suja (2010: 2) kearifan lokal juga dikenal dengan istilah kearifan tradisional karena keberadaannya sering dikaitkan dengan daerah atau etnik tertentu. Secara substantif menurutnya, kearifan lokal merupakan bagian dari suatu kebudayan yang sudah mentradisi dan menjadi milik kolektif serta bersifat fungsional untuk memecahkan masalah, setelah melewati pengalaman dan dimensi dalam ruang dan waktu secara berkelanjutan. Dalam pandangan lain, kearifan lokal akan mengacu pada berbagai kekayaan budaya yang bertumbuh dan berkembang dalam suatu masyarakat, dikenal, dipercayai dan dakui sebagai elemen-elemen penting yang mampu mempertebal hubungan atau kohesi sosial diantara warga masyarakat (Amirrachman, 200711). Bertolak dari pandangan tersebut, kearifan lokal dapat dikatakan sebagai norma atau nilai yang telah disepakati yang sudah terbukti dapat mempererat hubungan antar anggota masyarakat.

Di dalam kehidupan masyarakat Angantiga, kearifan lokal yang dimiliki tidak hanya menjadi ucapan semata, tetapi benar-benar sudah dilaksanakan dan tidak mempertentangkan siapa pemilik dari kearifan lokal tersebut. Salah satu budaya yang memiliki nilai sosial tinggi dan masih tetap dipertahankan hingga sekarang adalah kearifan lokal yang menjadi pedoman dalam kehidupan baik dalam hubungan antara manusia dengan pencipta-Nya, manusia dengan manusia maupun manusia dengan 
lingkungannya. Konsep ini melekat dalam fosofis Hindu yang dikenal dengan Tri Hita Karana. Istilah ini kalau diurai berasal dari kata tri artinya tiga, hita artinya senng atau gembira dan karana artinya sebab-musabab (Dharmayuda, 1991:6). Dengan demikian, Tri Hita Karana adalah tiga unsur penyebab yang dapat memunculkan kebahagiaan dalam hidup ini.

Selain itu masyarakat Petang yang bersifat heterogen juga dijumpai adanya kearifan lokal dalam bentuk kebijaksanaan atau pengetahuan asli suatu masyarakat yang berasal dari nilai luhur tradisi budaya untuk mengatur tatanan kehidupan masyarakat. Sehubungan dengan itu, ada beberapa norma sosial yang masih dijumpai di antaranya adalah tat twam asi yang artinya ia adalah kamu atau dengan kata lain saya adalah kamu dan segala makhluk adalah sama sehingga menyakiti orang lain berarti pula menyakiti diri sendiri (Astra, 2004:115). Konsep ini mengandung kesejajaran yang dapat diberlakukan pada semua umat manusia tanpa memandang suku atau keyakinan.

Nilai-nilai kearifan lokal sebagaimana yang dikemukakan tersebut pada dasarnya bersifat universal yang berlaku bagai setiap masyarakat termasuk dilakoni oleh kedua etnik dalam praktik kehidupan di Angantiga, Desa Petang, Badung.

\section{Adopsi unsur budaya}

Masyarakat Bugis yang dijumpai di Angantiga, Petang, umumnya menggunakan bahasa Bali dalam berkomunikasi dengan sesama warganya maupun dengan etnik Bali. Bahasa Indonesia sebagai bahasa komunikasi biasanya hanya dipergunakan pada saat acara formal seperti pertemuan atau rapat di Kantor desa. Penamaan Setra Bugis (bhs. Bali) juga digunakan untuk menamai kuburan untuk warga Bugis. Keberadaan Setra Bugis yang dijumpai, arealnya menyatu dengan Setra Bali dan hanya dipagari tembok pendek yang berfungsi sebagai pembatas dengan setra Bali. Persaudaraan di antara warga Bugis dan Bali di daerah Angantiga menurut kepercayaan masyarakat lokal sudah begitu menyatunya bukan saja saat mereka hidup di alam nyata saja, akan tetapi juga sampai ke alam kematian. Kondisi tersebut masuk akal jika dihubungkan dengan keberadaan Kuburan yang posisinya seperti metegen. Artinya kalau satu kuburan diisi untuk keseimbangan maka kuburan yang satunya juga akan diisi. Dengan demikian kalau ada 
warga Bugis yang meninggal untuk keseimbangan biasanya dalam waktu singkat akan ada warga Bali yang akan menyusul, demikian sebaliknya.

Konsep lain yang berkembang adalah menyama braya yang menjadi landasan dalam berinteraksi antaretnik Bali dan Bugis. Konsep ini berasal dari kata menyama dan braya. Menyama dalam arti sempit memiliki arti ikatan yang bisa terjadi karena hubungan darah atau hubungan perkawinan. Dalam artian luas menyama lebih ditekankan pada komunitas seperti banjar. Sedangkan braya lebih ditekankan pada hubungan pertemanan yang sangat akrab (Kabayantini, 2014). Berkenaan dengan itu, nyama braya mengacu pada pengertian adanya hubungan yang sangat akrab, bahkan karena saking eratnya dapat diibaratkan seperti hubungan yang dianggap dengan saudara sendiri.

Hubungan menyama braya di Angantiga kelihatan begitu eratnya antara anggota masyarakat satu dengan lainnya yang tidak memperhitungkan asal keturunan. Kondisi tersebut terlihat jelas dalam praktik sosial yang dikenal dengan istilah-istilah setempat seperti ngraris, majenukan, metetulung, dan ngayah (Haryanto, 2010). Ngraris adalah bentuk sikap turut bersuka pada saudara atau tetangga yang tengah mendapat kesenangan atau suka cita seperti peristiwa yang terkait dengan melahirkan bayi, dan pernikahan. Sebagai tanda ikut bersuka ria, biasanya tetangga dari keluarga yang memiliki hajatan akan berkunjung dan membawa baingkisan atau aba-abaan (barang bawaan) berupa beras atau gula dan barang lainnya yang dianggap memiliki manfaat.

Metetulung sebagai bentuk interaksi sosial antara etnik Bali dan Bugis adalah bentuk aktivitas saling membantu yang terjadi ketika warga kampung atau warga desa adat memiliki pekerjaan yang memerlukan bantuan tenaga (Parimartha, 2012:77). Kegiatan metetulung tersebut biasanya dilakukan, baik dengan cara diminta (mesuaka) atau tidak diminta. Akan tetapi dalam konteks tertentu, walaupun tidak diminta warga biasanya akan memberikan bantuan secara sukarela karena mereka merasa bersaudara (menyama) antara satu dengan lainnya.

Dalam peristiwa kematian dikenal istilah majenukan, yaitu suatu bentuk kunjungan yang dilakoni oleh keluarga atau tetangga lain kepada mereka yang memiliki halangan kematian yang berfungsi sebagai ungkapan perasaan ikut berdukacita atau ikut 
menghibur supaya tidak larut dalam kesedihan. Umumnya pada saat majenukan, mereka juga akan membawa aba-abaan (barang bawaan/ oleh-oleh) sebagai tanda ikut berduka.

Hal yang senada juga tampak dalam istilah budaya ngejot yang sering dilakoni oleh kedua etnik yang ada di Angantiga. Dalam konsep tersebut warga akan berbagi dalam bentuk saling memberi atau mengirimkan makanan pada saat mereka melakukan hajatan sebagai wujud ungkapan rasa syukur. Ketika ada salah satu warga kampung yang mengadakan acara pernikahan, kelahiran atau perayaan lainnya, umumnya ia akan mengantarkan makanan kepada warga lainnya. Contoh lain adalah pada saat hari raya Idul Adha, warga Bugis (muslim) akan melakukan potong kambing sebagai kurban. Pada itu mereka juga akan melakukan kegiatan ngejot kepada warga lain yang berbeda keyakinan yaitu warga Hindu yang sudah dianggap sebagai saudara atau nyama Bali. Kegiatan ini juga ada timbal baliknya, artinya saat hari raya Galungan, warga Bali juga akan melakukan hal yang sama yakni ngejot berupa pemberian makanan kepada warga beragama Islam sebagai tanda mereka adalah bersaudara.

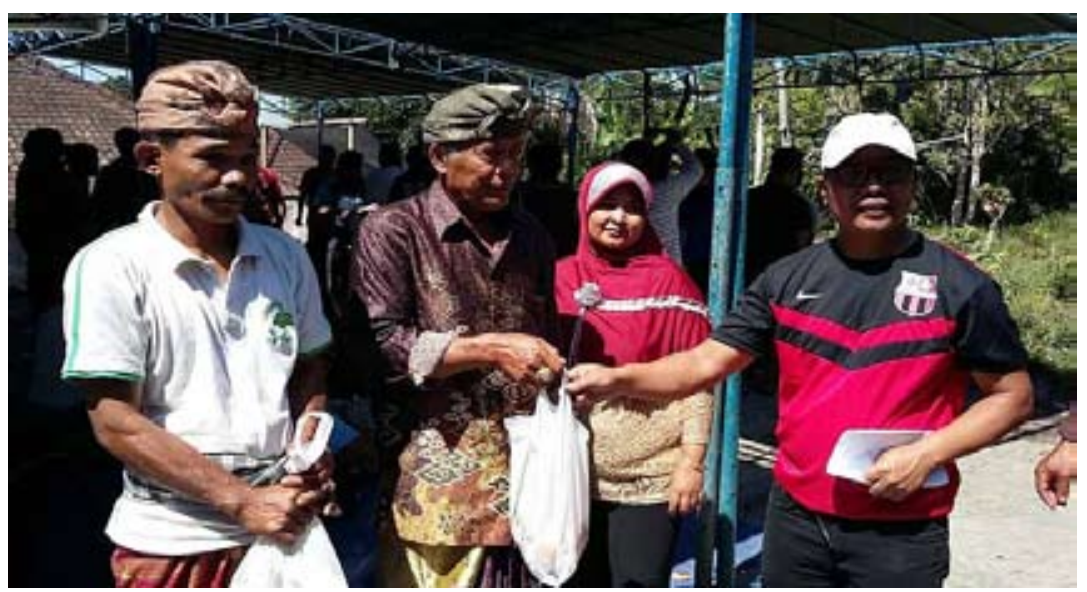

Foto 2. Ngejot Daging Kurban saat Hari Idul Adha (doc.Penulis)

\section{Kegiatan gotong royong}

Pembauran warga Bugis dan Bali masih kental terjadi di beberapa daerah termasuk di Angantiga. Kegiatan biasanya diwujudkan dalam bentuk saling bantu dalam persiapan upacara perkawinan, kematian dan upacara besar keagamaan kedua etnik seperti dalam 
menyongsong hari Nyepi dan Idul Fitri. Dalam rangka persiapan kedua hari besar tersebut, masing-masing etnik terlibat secara intensif misalnya dalam menjaga prosesi upacara masing-masing. Pada saat hari pengerupukan misalnya, warga Bugis biasanya akan ikut mengamankan acara pengrupukan dalam arak-arakan ogohogoh keliling desa. Ketika hari nyepi tiba, dimana warga Hindu melaksanakan brata penyepian dengan tidak boleh keluar rumah, tidak boleh bekerja, tidak boleh melakukan hiburan, dan tidak boleh menghidupkan api, warga Bugis (Islam) juga turut membantu dalam pengamanannya. Demikian juga sebaliknya, pada saat umat Islam melaksanakan sholat Idul Fitri, ataupun Idul Adha dimana jemaah meluber di mesjid setempat, maka pecalang dari banjar adat Angantiga juga ikut membantu mengamankan lokasi sehingga tidak menganggu kekhusukannya dalam melakukan sembahyang.

Selain itu, kegiatan gotong-royong juga tampak dalam bentuk kerja bakti membersihkan desa yang dilakukan secara rutin oleh warga masyarakat setiap bulan sekali dan saat menyongsong perayaan kemerdekaan Republik Indonesia 17 Agustus. Kegiatan ini secara langsung atau tidak langsung mendekatkan di antara mereka sebagai usaha untuk membangun integrasi sosial yang langgeng tanpa diliputi suasana saling curiga.

Kegiatan yang tidak kalah menariknya juga tampak dalam acara gotong-royong dalam pembersihan lahan pertanian sawah atau ladang yang dimiliki oleh kudua etnik termasuk dalam persiapan upacara yang terkait dengan budaya pertanian. Hingga saat ini, warga muslim Angantiga juga banyak yang bermata pencaharian sebagai petani dengan mengandalkan bercocok tanam di sawah maupun menanam tanaman komuditi perkebunan seperti kopi, fanili ataupun cengkeh di ladang yang dimiliki. Sehubungan dengan itu, mereka juga secara langsung akan terlibat dalam organisasi Subak setempat baik yang terkait dengan subak basah (sawah) maupun subak kering (tegalan). Dalam acara prosesi ritual yang dikenal dengan mapag toya (menyambut air) yang dilakukan saat awal musim tanam, warga muslim Angantiga juga terlibat secara aktif. Warga Hindu saat itu biasanya melakukan ritual tersebut dengan menghaturkan sesajen di pura subak setempat. Sedangkan warga Muslim biasanya akan menyelenggarakan acara mapag toya di rumah anggota subak yang beragama Islam di lokasi dekat sawah atau tegalannya tentunya dengan tata cara Islam yang 
mereka yakini.

\section{Simpulan}

Bertolak dari penelitian yang dilakukan, maka dapat diberikan kesimpulan sebagai berikut.

Pertama, keberadaan etnik Bugis di Angantiga secara historis tidak dapat dilepaskan dari penghargaan Raja Carangsari terhadap warga Bugis yang dipimpin oleh Daeng Mapilih atas keberhasilannya mengamankan daerah Bangkiang Jaran yang sebelumnya dianggap rawan oleh penduduk.

Kedua, hubungan Warga Bugis dengan Puri Carangsari merupakan bentuk hubungan kaula-gusti (patron- client) yang saling menguntungkan yang praktiknya dapat dilihat dengan masih dipertahankannya tali silahturahmi antara kedua belah pihak. Pihak puri akan memohon bantuan pada warga Bugis ketika memiliki hajatan besar seperti piodalan. Sebaliknya warga Bugis juga akan memohon pihak Puri untuk menghadiri upacara keagamaan, seperti Hari Idul Fitri maupun Idul Adha.

Ketiga, kearifan lokal yang dipraktikkan dalam kehidupan se hari-hari mendorong terwujudnya integrasi sosial di masyarakat sehingga harmonisasi terjaga dengan baik antaretnik Bugis yang beragama Islam dan etnik Bali yang beragama Hindu. Kearifan dimaksud menyangkut nilai atau norma, seperti Tri Hita Karana, Tat Twam Asi ataupun dalam bentuk jaringan sosial seperti tampak dalam budaya ngejot, menyama braya, ngraris, majenukan, metulungan, dan praktik budaya lainnya.

\section{Daftar pustaka}

Amirrachman, Alpha. 2007. Revitalisasi Kearifan Lokal Studi Resolusi Konflik. Jakarta: ICIP

Bogdan, R \&Taylor. 1975. Introduction to Qualitative Research Methods. New York: John Wiley

Dharmayudha, I Made, Koti Cantika, I Wayan. 1991. Filsafat Adat Bali. Denpasar: Upada Sastra

Dwija, I Nengah. 2006. “Revitalisasi Model Sosial Mayarakat Bali Berbasis Kearifan Lokal", dalam Suacana (ed), Bali Bangkit. Denpasar: Universitas Udayana.

Haryanto, Joko Tri. 2010. Mengenal Sekilas Kampung Islam Angantiga Petang-Bali. Semarang: Balitbang Agama. 
Ismail, H. Arifuddin. 2010. Revitalisasi Kearifan Lokal Dalam Mayarakat Multikultural. Semarang: Balai Penelitian dan Pengembangan Agama

Liliweri, Alo. 2005. Prasangka dan Konflik Komunikasi Lintas Budaya Masyarakat Multikultur. Yogyakarta: LKis

Kabayantini, Ni Luh. 2014.Pergeseran Makna Budaya Menyama Braya. Saraswati 12(1) : 8-11

Molan, Benyamin. 2015. Multikulturalisme Cerdas Membangun Hidup Bersama yang Stabil dan Dinamis. Jakarta: PT Indeks

Pageh, I Made, Sugiartha, Wayan dan Sudana, Ketut. 2013. “Faktor Integratif Nyama Bali-Nyama Selam: Model Kerukunan Masyarakat pada Era Otonomi", Jurnal Kajian Bali. Vol 3(1): 191206.

Parimartha, I Gede, Putra, I.B, Kusuma Ririen, Luh Putu. 2012 Bulan sabit Di Pulau Dewata Jejak Kampung Islam Kusamba-Bali. Yogyakarta: Universitas Gajahmada

Suja, I Wayan. 2010. Kearifan Lokal Sains Asli Bali. Surabaya: Paramita.

Suwitha, Putu Gede. 2014. Dinamika Mayarakat Bugis di Kabupaten Badung dan Kota Denpasar. Disertasi, Program Pascasarjana Universitas Udayana. Denpasar. 